\title{
A review of work-integrated learning in South African mining engineering universities
}

\author{
by L.A. Maseko*
}

\section{Synopsis}

As part of the mining engineering curriculum, students are required to be placed in industry for vacation work or work-integrated learning (WIL). In this paper we review work-based placement as done at the four South African mining schools: the University of Johannesburg, the University of Pretoria, the University of the Witwatersrand, and the University of South Africa.

Key aspects of past and current WIL (pre- and post-graduation) practices that may need attention are highlighted for consideration by all universities that provide professional qualifications. Work-directed theoretical learning, problem-based learning, project-based learning, workplace learning, and simulated work experiences are discussed as legitimate approaches to WIL.

Regardless of the choice each institution makes, commitments of universities, preparedness of university teachers, and the desire for equity and excellence will play an important role in the provision of WIL.

Keywords

mining engineering programmes, vacation work, work-integrated learning, experiential learning, work placement, work-based learning.

\section{Definitions}

Accredited Qualification: a qualification awarded on successful completion of an accredited programme.

Advisory Boards (or Committees): are essential infrastructure for a WIL curriculum that is built on the integration of the workplace and the university. This requires the collaboration of experts from both environments. Workplace advisors are critical to the success of the academy as they embody expert knowledge of the 'real world'.

Assessment: the process of determining the capability or competence of an individual against standards by evaluating performance.

Category: a mode of registration defined in or under the ECSA Act which has a distinctive purpose, characteristic competencies, defined principal routes to registration, and educational requirements.

Experiential learning: (in South Africa sometimes used synonymously with work placement or cooperative education) is a term used with a great variety of meanings in the international literature. More broadly, it may refer to learning that has meaningful learner involvement. It is the process of generating meaning from direct experience. In the international literature, experiential learning is learning through reflection on doing, which is often contrasted with rote or didactic learning. Graduate: a qualifying learner, irrespective of whether the qualification is a degree or a diploma.

Level: a measure of learning demands in terms of types of problems, knowledge required, skills, and responsibility, expressed in terms of level descriptors.

Level descriptor: a measure of performance demands at which outcomes must be demonstrated.

Practicum: a period of work that provides the student with the opportunity for practical experience in the real world as part of an academic programme.

Problem-based learning (PBL): a term used in higher education for a range of pedagogic approaches that encourage students to learn through the structured exploration of a research or practice-based problem (SavinBaden and Major, 2004).

Programme: a structured, integrated teaching arrangement with a defined purpose and pathway leading to a qualification.

Project-based learning (PJBL): combines PBL and workplace learning in that it brings together intellectual inquiry, real-world problems, and student engagement in relevant and meaningful work. Project work is generally understood to facilitate students' understanding of essential concepts and practical skills.

Qualification: the formal recognition of a specified learning achievement, usually awarded on successful completion of a programme.

* University of South Africa, Unisa Science Campus, South Africa.

(c) The Southern African Institute of Mining and Metallurgy, 2018. ISSN 2225-6253. Paper received May 2018; revised paper received Aug. 2018. 


\section{A review of work-integrated learning in South African mining engineering universities}

Simulated learning: learning through an activity that involves the imitation of the real world in the academy. The act of simulating something entails representing certain key characteristics of the selected workplace and includes such things as laboratories, patient models, mock meetings, flight simulations etc.

Standards: in the context of engineering training programmes, statements of outcomes to be demonstrated, the level of performance, and content baseline requirements.

Work-based learning: has been defined as 'learning for, at, or through work' (Brennan and Little, 1996). WBL involves the acquisition of work-related knowledge and skills both in the university and in the workplace, with the formal or nonformal involvement of employers (Boud and Solomon, 2001).

Work-directed theoretical learning: involves an attempt to ensure that theoretical forms of knowledge (such as mathematics and physics in engineering programmes) are introduced and sequenced in ways that meet academic criteria and are applicable and relevant to the career-specific components (Barnett, 2006).

Work-integrated learning: an umbrella term for describing curricular, pedagogic, and assessment practices across a range of academic disciplines that integrate formal learning and workplace concerns.

Work placement: a way of gaining 'on the job' experience in the real world. Work placement is part of the curriculum design for WIL for professional qualifications. The aim of a work placement is to develop the student as a professional through observation, participation, and completion of tasks that demonstrate competency.

\section{Introduction}

One may ask whether there is any need to investigate workintegrated learning (WIL) in the context of engineering education. The answer to this question lies in the changes worldwide in the nature of work. There is also currently a debate about excellence and equity in the field of sociology of education, and this further underlines the importance of reflecting on how we conduct WIL. Indeed, the changing patterns of technology have altered the demand for particular occupations and skills. This, in turn, requires that employees' skill and knowledge levels are developed continuously; hence the renewed interest in WIL.

Increased global competition among institutions for students has contributed significantly to the changed status of WIL in higher education. Gamble, Patrick, and Peach (2010) have proved that WIL can help students develop selfmanagement, conceptual, and analytical skills, personal and professional effectiveness, communication and problemsolving skills, as well as workplace flexibility. It is because of this potential that students who have participated in WIL programmes are sought after in Australia. Blicblau, Nelson, and Dini (2016) found that students who spent time on WIL or industry-based learning (IBL) in the penultimate year of their engineering course obtained better marks than those who did not undertake such a placement.

Although different universities use various terminologies to describe their programmes and practices, all are based on similar understanding of the importance of enabling students to integrate theoretical knowledge gained through formal study with the practice-based knowledge acquired by immersion in a work or professional context. It is important to point out that the work-based training takes place before as well as after graduation, where it is referred to as training and development programme.

In this paper we review work-based placement as done at the four South African mining schools: at the University of Johannesburg (UJ), the University of Pretoria (UP), the University of the Witwatersrand (Wits), and the University of South Africa (Unisa). New qualifications have been approved and universities have decided on qualifications that they want to offer as presented by the Engineering Council of South Africa (ECSA), approved and finalized by the Council on Higher Education (CHE). Consequently, new content needs to be developed, and some institutions have started following guidelines provided by the CHE in conjunction with ECSA. In order to appreciate WIL further, it may be necessary to reflect on its origin to place the discussion in the right context.

\section{Work-integrated learning: background}

Theories of education have been developed over the years to explain how students learn outside the classroom. The aim of this section is to highlight those basic education theories that are a foundation to WIL programmes, and then reflect on current practices of the various mining schools that are offering experiential learning as part of their programmes.

\section{Origins of experiential learning}

Dewey (1938) was one of the first educational theorists who held the view that people learn by doing. He further emphasized the notion that genuine education is achieved through experience. His theory also stressed the importance of any chosen career encompassing critical and scholarly engagement with the key issues of public life that link professional and vocational competence.

Kolb (1984) pointed out that experiential learning is a dialectic and cyclical process consisting of four stages: experience, observation and reflection, abstract reconceptualization, and experimentation.

While experience is the foundation for learning, learning cannot take place without reflection. In the same manner, while reflection is essential to the process, it must be integrally linked with action. Schön (1983) acknowledged the importance of reflection and reflective practice in the education of professionals. This implies that reflective theory works in the context of the experiential learning cycle in Figure 1. In simple terms, Schön advocated practice first, then integrating theory and practice, thought, and finally action.

More recently, the theoretical foundation of the experiential learning cycle by Kolb (1984) and the reflective practitioner model by Schön (1983) have been challenged. The basis for the challenge is that people do not necessarily learn from experience and general reflection. This is particularly true if they do not think critically about their learning or do not take responsibility for its creation. Such learning should not be seen as the only approach to gain information about the workplace and to link technical knowledge with workplace application for it to be effective. 


\section{A review of work-integrated learning in South African mining engineering universities}

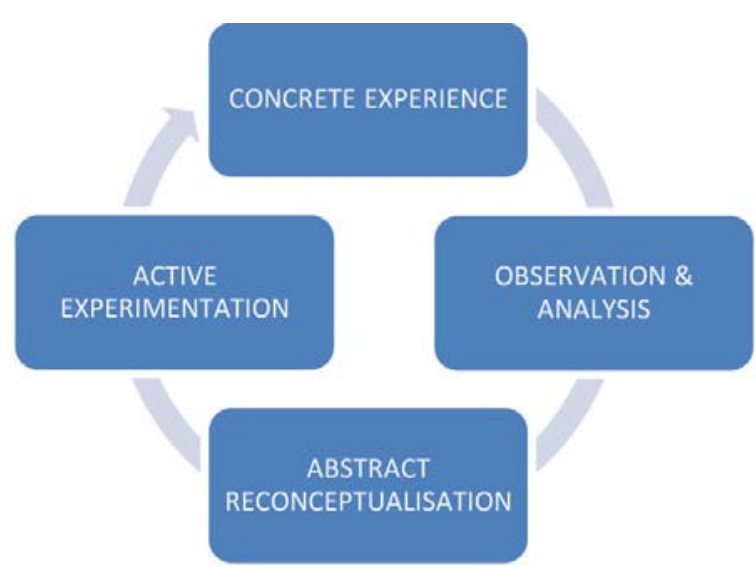

Figure 1-Experiential learning cycle

Biggs (1999) claims that effective learning requires a knowledge base, a motivational context, learning activities, and interaction in the higher education context. For learning to occur, students need to observe and reflect on experience, develop concepts to make sense of the experience, and then apply and test these concepts through new experiences.

Yorke (2006a, 2006b) argues that WIL is not simply a process of students engaging in work experience with the hope that it will result in employability. Instead, it is an educational process, service, and experience, with foundational pedagogy and theory (Moreland, 2005; Yorke, 2006a; Yorke and Knight, 2006), and can be aligned with the processes and outcomes of experiential learning (Kolb, 1984), which seeks to secure and maximize learning through experience, often outside the traditional sphere of education.

When all is said and done, experiential learning as the process of gaining meaning from direct experience is intrinsic to WIL. Understanding the experiential learning cycle by Kolb (1984) and reflective practitioner model by Schön (1983) offers a valuable contribution to curriculum reform and design and can help to inform quality assessments as well.

\section{The South African context}

The quality of education in South Africa was a burning issue, even long before the dawn of democracy in 1994. To this day, education providers and all the stakeholders involved are still struggling with the problem.

The new democratic government of South Africa, after taking power in 1994, had to attend to the problems created by the former apartheid regime. These problems revolved around two main issues: a hostile work environment and an educational system that was failing the citizens. This explains why the protest action was led predominantly by the trade unions and students.

In the workplace, the demands in the early 1970s for a better wage were rejected by employers on grounds that workers were unskilled and therefore could not justify their demands. In the quest to address their needs, workers began to see training as a means to obtain better wages. It was during the same period in the mid-1970s that the educational system was challenged by activists, and this culminated in the 1976 Soweto student uprisings.
A number of stakeholders led the change in South Africa. Resistance in the non-governmental educational sector eventuated in the birth of the National Education Policy Initiative (NEPI), which was to develop proposals for the restructuring of the formal education system. This involved discussions with a wide range of stakeholders within the democratic alliance. The NEPI reports and framework, which was published in 1992, were based on the principles of nonracism, non-sexism, democracy and redress, and the need for a non-racial unitary system of education and training. COSATU played a crucial role in the NEPI process until the dawn of democracy in 1994.

The meeting between the Department of Manpower and the trade union federations in 1992 led to the formation of a representative task team, which established eight working groups charged with developing a new national training strategy. Represented in the working groups were trade unions, employers, the State, providers of education and training, the ANC Education Department, and the democratic alliance (SAQA, 2010).

All the processes and discussions that took place for the purpose of rebuilding the country did not necessarily go smoothly. Task teams and working groups were established with the sole aim of arriving at solutions, but there were challenges that involved legitimacy, exclusion, and difficulty in handling differences of opinion. Despite these challenges, in 1995 there was a significant improvement in the government's Reconstruction and Development Programme.

The establishment of the NQF by the government, labour movement, and organized business brought a new hope for the future of education in South Africa. It was envisaged that the NQF would open up learning and career pathways for all South Africans, irrespective of their previous formal education, training, or work experience. The South African Qualifications Authority (SAQA) Act, which was passed in 1995, established SAQA to oversee the development and implementation of an integrated national framework of quality-assured learning. The focus areas for SAQA's mandate include facilitation of access; mobility and progression within education, training, and development; enhancing the quality of education and training; accelerating redress of educational and job opportunities; and advancing personal, social, and economic development (SAQA, 2002)

The process of refining the NQF later became a central issue on the agenda of improving education and training. This is so because the South African NQF is comprehensive and complex in nature and therefore requires a lot of adjustment. One of the major adjustments was the introduction of changes based on organs that are responsible for qualifications and quality assurance. These Quality Councils (QCS) have been established for General and Further Education and Training, Higher Education, and Trades, Occupations, and Professions. The appropriate QCs that have been identified are, respectively, Umalusi, the CHE, and the new QC for Trades and Occupations (QTCO). The National Qualifications Framework Act No. 67 of 2008 gives legislative effect for these changes (SAQA, 2010). In the light of these changes, one cannot ignore the complexity of addressing the abovementioned initiatives.

The compelling reason for mining engineering universities to revisit WIL is the need to reflect on and to look 


\section{A review of work-integrated learning in South African mining engineering universities}

for possible areas of improvement in order to contribute positively towards enhancing the quality of education in the country. This is widely acknowledged to be pivotal in preparing engineers, technologists, and technicians who are able to function efficiently in the 21st century. Experiential learning or WIL forms an important part in this process of developing young professionals who are expected to lead the mining industry in the future. The $\mathrm{CHE}$, through its subcommittees, plays a very important role in the process to inform all necessary changes in education.

The Higher Education Quality Committee (HEQC) established a project in 2002 to prepare the core functions of teaching and learning in the tertiary education sector. The key objective was to restructure higher education in the context of tuition while developing a national quality assurance system. In March 2005, the HEQC published the Improving Teaching and Learning (ITL) resource as its priority to address quality issues in teaching and learning (CHE, 2005). Since then, there have been a number of teaching- and learning-related publications. Examples include 'Service-learning in the curriculum: A resource for higher education institutions' (2006), 'Higher Education Monitor: A case for improving teaching and learning in South African higher education' (2007), and 'Higher Education Monitor: Access and throughput in South African higher education - three case studies' (2010). These have served to increase the level of national and institutional debate on the conceptualization, quality, and practice of teaching and learning.

The heart of the HEQC approach since its inception has been the concept of initiating and facilitating quality-related activities for capacity development in higher education in collaboration with relevant stakeholders. These activities included large dedicated projects in selected areas such as workshops, training sessions, seminars, and publications. It is because of these activities that the CHE WIL Good Practice Guide was published in 2011.

The CHE WIL Good Practice Guide (2011) is currently used for the development of the new Programme Qualification Mix (PQM) by universities in South Africa. The guide was produced in the context of the promulgation of the Higher Education Qualification Framework (HEQF) and processes of national curriculum review. The HEQF proposed six higher education levels (Levels 5-10), with different qualifications requiring appropriate credits at different levels

(Table I).

This guide is intended to assist academic staff, particularly where existing programmes are undergoing revision, in developing appropriate forms of WIL for different levels of the HEQF. The guide is comprehensive in nature and covers a conceptual framework for WIL, curriculum design and development for WIL, teaching and learning for WIL, assessment for/of WIL, partnerships for WIL, and the management of WIL.

As indicated before, the CHE continuously monitors the education system in the country and gives advice to institutions of higher learning on issues that need attention. The latest publication, 'Learning to teach in higher education' (2017), still emphasises the need for university lecturers/teachers to improve in pedagogy. This indicates that tuition and learning matters are going to be areas of focus in the future, and WIL education falls in that category.

\section{Work-integrated learning programmes}

Different institutions use different terms to describe workintegrated learning (WIL), which can cause confusion. Patrick et al. (2008) list the following terms: practicum, professional practice, internship, workplace learning, industry-based learning, project-based learning, cooperative education, fieldwork education, service learning, real-world learning, university-engaged learning, placements, experiential learning, clinical placement, and professional placement, to mention but a few.

According to the CHE WIL Good Practice Guide (2011), work-integrated learning is used as an umbrella term to describe curricular, pedagogic, and assessment practices across a range of academic disciplines that integrate formal learning and workplace concerns. It is this definition on which this paper is based.

Theory and practice in student learning can be integrated through a range of WIL approaches, apart from formal or informal work placements. The CHE WIL Good Practice Guide (2011) identifies four modes of approach to WIL: workdirected theoretical learning (WDTL), problem-based learning (PBL), project-based learning (PJBL), and workplace learning (WPL). Simulated work experiences have been identified as a

\begin{tabular}{|c|c|}
\hline \multicolumn{2}{|l|}{$\begin{array}{l}\text { Table I } \\
\text { Higher education NQF levels }\end{array}$} \\
\hline NQF Level & Qualification type \\
\hline 10 & Doctorates (PhD); post-doctoral studies [360 credits] \\
\hline 9 & Master's degrees [180 credits] \\
\hline 8 & $\begin{array}{c}\text { Professional 4-year Bachelor's degrees; Bachelor honours degrees [480 credits] } \\
\text { Professional Engineering 4-year Bachelor's degrees; } \\
\text { Bachelor honours [BEng: 560 credits] }\end{array}$ \\
\hline 7 & $\begin{array}{c}\text { Bachelor's degrees; advanced diplomas (third-year level) [360 credits] } \\
\text { Professional Engineering 3-year Bachelor's degrees; } \\
\text { [BEngSc: 360 credits]; [BEngTech: 420 credits] }\end{array}$ \\
\hline 6 & $\begin{array}{r}\text { Diplomas, advanced certificates (first- and second-year levels) } \\
\text { [240 credits - 360 credits] }\end{array}$ \\
\hline 5 & $\begin{array}{r}\text { Higher certificates; Foundation modules [120 credits] } \\
\hline\end{array}$
\end{tabular}




\section{A review of work-integrated learning in South African mining engineering universities}

legitimate option available that industry and tertiary educational institutions can use to implement WIL.

Table II provides an overview of the most common types of approach to WIL curricular practice recommended by the CHE.

Based on Table II, university lecturers are expected to negotiate boundaries of the education theories and design appropriate curricula for pre-graduation WIL. The curricula should align teaching and learning with the course outcomes. In addition to this, assessment practices should also be aligned with the intended outcomes.

In order to ensure that quality is improved, these programmes need to be evaluated. Smith (2012) identifies the key dimensions of the different WIL programmes for evaluation as including authenticity, integrated learning support (both at university and the workplace), alignment (of teaching and learning activities and assessments with integrative learning outcomes), supervisor access, and induction/preparation processes. He then suggests that the variations in the way that WIL courses or subjects are designed within these dimensions are the basis for different expressions of the quality of such courses.

\section{Work-integrated learning at South African universities}

The mining universities in South Africa currently use two different models for work placement to fulfil WIL requirements in their programmes. It should be noted that the concepts alluded to in this paper apply to each of the nine recognized engineering disciplines, although the context may be subject to the requirements of each discipline. The first approach is where the work placement component is embedded in the National Diploma qualifications offered by universities of technology or comprehensive universities, and is referred to as experiential learning (Unisa and in this case UJ). In the context of universities of technology or former technikons, the term 'experiential learning' was used synonymously with work placement; it is not the case in this paper). In the curriculum these are referred to as Mining Engineering Practices 1 and 2 (popularly known as P1 and P2) to indicate that they are done in two semesters. It should be noted that that P1 and P2 are being phased out at UJ and the university is moving towards a 3-year BET degree. This is a similar approach to that of Wits and UP.

P1 and P2 have clearly defined activities stipulated in the logbook. These activities include exposure of the student to basic mining and technical services in the operation. The first part of the assessment is carried out in industry by a mentor who declares the student to be competent after all the requirements in the logbook have been met. The summative assessment will then be carried out by the university lecturer. The student submits a record of all the work done in the workplace in the form of a portfolio. The required period of placement for this type of WIL is a minimum of one year in the workplace. This placement can be continuous or done in two parts in different years, depending on the institution. In many instances the student will come out with a national rock-breaking certificate (NQF level 3 ) at the end of $\mathrm{P} 2$. It is important to note that this approach was not based on ECSA exit level outcomes but it contributed to enhancing the learning. The new PQM will accommodate the ECSA exit level outcomes.

The second model is what is referred to as vacation work by universities that offer the Bachelor's qualifications (Wits and UP in this case). In this model the students are required to attend an engineering workshop at the end of their first year. In their second year the students are exposed to practical training on a mine, focusing on mining activities. This where the students complete the Competent Person A and Competent Person B qualifications. The focus of this training includes examination, declaring a workplace in the mine to be safe, and carrying out all practical mining tasks in a safe manner. Both of these skills programmes are accredited by the Mining Qualifications Authority (MQA). The third year is dedicated to project work for the dissertation. The total duration of exposure amounts to eight

Table /I

A work-integrated learning typology (CHE, 2011)

\begin{tabular}{|c|c|c|c|c|}
\hline $\begin{array}{l}\text { Curricula } \\
\text { modality }\end{array}$ & WDTL & PBL & PJBL & WPL \\
\hline $\begin{array}{l}\text { Terms and } \\
\text { practices } \\
\text { associated }\end{array}$ & $\begin{array}{l}\text { Classroom-based } \\
\text { instruction, lecture, tutorial, } \\
\text { peer learning groups }\end{array}$ & $\begin{array}{l}\text { Sequenced real-world } \\
\text { problems, integrated } \\
\text { learning, discovery learning, } \\
\text { self-directed learning, } \\
\text { peer learning groups }\end{array}$ & $\begin{array}{l}\text { Industry project, real-world } \\
\text { learning, guided practice, } \\
\text { capstone modules }\end{array}$ & $\begin{array}{l}\text { In-service work } \\
\text { placements, cooperative } \\
\text { education, practicum } \\
\text { work-based learning, } \\
\text { sandwich courses, } \\
\text { apprenticeships, } \\
\text { internships, traineeships }\end{array}$ \\
\hline Examples & $\begin{array}{l}\text { Career focused courses and } \\
\text { curricula (e.g., maths for } \\
\text { engineering, communication } \\
\text { for business), guest } \\
\text { lecturers (e.g., from industry), } \\
\text { authentic examples, } \\
\text { workplace assessors }\end{array}$ & $\begin{array}{l}\text { Work-simulated problems, } \\
\text { case studies and scenarios, } \\
\text { team learning }\end{array}$ & $\begin{array}{l}\text { Study visit, site visit, job } \\
\text { shadowing, authentic tasks } \\
\text { and texts, fieldwork, } \\
\text { interviews, team work, } \\
\text { service learning, integrated } \\
\text { trans- or inter-disciplinary } \\
\text { projects }\end{array}$ & $\begin{array}{l}\text { Learning contracts, work } \\
\text { record books, learning } \\
\text { logs, journals, mentoring, } \\
\text { specific training, learning } \\
\text { portfolios }\end{array}$ \\
\hline $\begin{array}{l}\text { Site of } \\
\text { learning }\end{array}$ & $\begin{array}{l}\text { Lecture theatre, classroom } \\
\text { laboratory, studion, websites } \\
\text { blogs }\end{array}$ & $\begin{array}{l}\text { Classroom, laboratory, } \\
\text { group sessions, library, } \\
\text { electronic media }\end{array}$ & $\begin{array}{l}\text { Multiple sites: classroom } \\
\text { and workplace, laboratory } \\
\text { and workplace, electronic } \\
\text { media etc. }\end{array}$ & $\begin{array}{l}\text { Workplace and classroom } \\
\text { (for preparation and } \\
\text { reflection) electronic } \\
\text { media }\end{array}$ \\
\hline
\end{tabular}




\section{A review of work-integrated learning in South African mining engineering universities}

weeks in industry per year in the first three years at university. In addition, students are taken for mine tours, survey camps in the middle of their third year, and mine visits in their fourth year. A university can arrange these activities in a manner that suits its particular calendar.

The assessment criteria in the vacation work model can be in the form of projects that students carry out while in the industry. The industry mentor plays an important role in identifying the project in the mine and also in reviewing the project report of the student for facts and accuracy of content. At the end of the vacation work, the summative assessment will be carried out by the university to gather evidence of the student's critical analysis skills, good organization, clarity, and conciseness. This will be clearly demonstrated in the dissertation that the student submits to the university. Practical mining is assessed through the Competent Person A and Competent Person B reports.

Student placement forms an important part in the provision of WIL at all the universities. The MQA has played a very significant role in helping universities to place students in mines. There are also challenges associated with the placement of students. These challenges include failure to implement agreements between the MQA and some mining companies, resulting in fewer placement opportunities.

In the past, universities such as Wits, UJ, and UP were easily able to place students in the industry. However, this has been changing due to the economic situation in the mining industry. Wits and UP currently have embarked on new initiatives to complement the learning activities of their students.

UP has a Virtual Reality Centre for Mine Design which aims to enhance education, training, and research in operational risk across industries through an innovative approach to information optimization and visualization (UP, 2018). Wits has the Digimine laboratory, the sole purpose of which is to make mining safer and more sustainable using digital technologies. This project comprises a mock mine equipped with a life-size tunnel, stope, lamp room, and other features (Wits Mining Institute, 2018). Both initiatives contribute immensely in exposing students to a similar environment to that of the real world. Given the limitation of the resources, this will help the students to understand the concepts in the curriculum. After graduation, students can then build their skills set using the graduate development and training programmes outlined by ECSA.
An open distance learning (ODL) institution such as Unisa faces challenges in placing international students, especially those from elsewhere on the African continent, owing to the great number of such students and the fact that they study in their home countries. The effective placement of international students is currently possible for those who have financial resources to travel, and the Colliery Training College has contributed towards alleviating the problem by accepting such students. The other solution is for students to be placed in their respective countries where possible, but that entails its own challenges.

Despite the placement challenges, both of the work placement models outlined above contribute to a certain extent to students' learnings, but involve quality assurance difficulties. Some issues that affect the quality include induction/preparation processes; industry mentor readiness, access, and qualifications; authenticity; integrated learning support by both the university and industry; and alignment of teaching and learning activities and assessments with integrative learning outcomes, as alluded to by Smith (2012).

Effective WIL programmes require policies that guide the offering of work placements. From a scan of the websites and related policies of the four universities (Wits, UJ, Unisa, and UP), the terms 'work-integrated learning' seem to describe educational programmes that are linked to work placement.

It is important to note that no specific policy for experiential learning was found for Wits or UP. Universities that are developing the new curriculum and those that are not need to consider the guidelines offered by the CHE to overcome deficiencies in their programmes and align the outcomes with the NQF levels and ECSA exit-level outcomes.

\section{Partnerships for pre-qualification WIL}

WIL programmes cannot be effective until all stakeholders involved take part in implementation. The objective of the WIL programme should be to build linkages between workplace knowledge and the academic curriculum. It should also be to help students transfer academic knowledge to workplaces. Therefore, commitment is necessary from both academic and professional partners representing the different knowledge fields to construct effective WIL programmes (CHE, 2011).

According to a study by Pennaforte (2015), studentworkers' perception of co-workers and supervisor support helps them to develop commitment to the teams in the

Table III

WIL policies of the various institutions

\begin{tabular}{|l|l|}
\hline University & WIL policy \\
\hline University of Johannesburg & $\begin{array}{l}\text { WIL - The component of a learning programme that focuses on the application of learning in an } \\
\text { authentic learning work-based context under the supervision and/or mentorship of a person/s } \\
\text { representing the workplace. It addresses specific competencies identified for the acquisition of } \\
\text { a qualification that make the learner employable and assist in the development of related } \\
\text { personal attributes. Workplace/service employees and professional bodies are involved in the } \\
\text { assessment of the learning experience, together with university academic employees. }\end{array}$ \\
\hline University of South Africa & $\begin{array}{l}\text { WIL is used as an umbrella term to describe curricular, pedagogic, and assessment practices } \\
\text { across a range of academic disciplines that integrate formal learning and workplace concerns. }\end{array}$ \\
\hline University of the Witwatersrand & WIL policy could not be found \\
\hline University of Pretoria & WIL policy could not be found \\
\hline
\end{tabular}




\section{A review of work-integrated learning in South African mining engineering universities}

workplace. Bravenboer and Lester (2016) provide some evidence that where competence is conceived of as a matter of open ongoing professional development, it can be integrated and aligned effectively with the intended outcomes of academic qualifications. This finding further indicates the importance of bringing together academic institutions and professional bodies.

Partners can be divided into two types: internal and external. The internal partners include university teachers and departmental colleagues (including faculty officers and placement officers), faculty or institutional centres or units that support WIL, and students. External partners include potential employers, professional practices, companies (particularly those that have a commitment to education), community partners (including non-governmental organizations, community-based organizations, non-profit organizations, etc.), government departments, sector education and training authorities such as the MQA, and professional bodies such as ECSA and the Southern African Institute of Mining and Metallurgy (SAIMM). In large companies, the training manager, who is usually located in the human resources department, can act as a supportive partner for WIL.

The most important player in WIL is the mining industry. This industry faces challenges regarding its contribution to student placement from time to time. Some of the challenges are commodity price fluctuations that lead to cutbacks in training as the first cost-saving resort, production pressure which affects the training of students, lack of training capacity on small mines, and the lack of suitable mentors, as there are still many shift supervisors (shift bosses), mine overseers, and even managers in some mines who have government certificates of competency but no tertiary qualifications. This affects the quality of the training of students on mines, because those supervisors may not be familiar with the university curriculum content and so be unable to help student to link the theoretical aspects accurately with the real world. The other notion in the industry is that students from universities will be promoted quicker when they have entered employment, hence a hostile atmosphere prevails and prevent effective learning. The abovementioned barriers and others have to be interrogated in our plans to review our current practices of WIL.

\section{The role of ECSA in training and mentoring}

Although ECSA has been mentioned as one of the partners, it is important to focus on its role because of the unique responsibilities of this institution. The core functions of ECSA include: (i) the accreditation of engineering programmes, (ii) registration of persons as professionals in specified categories, and (iii) the regulation of the practice of registered persons. This clearly indicates that ECSA is involved in all aspects of engineering education and practice.

WIL is one aspect that is addressed in the engineering programmes before graduation in order to fulfil all the requirements for qualifications to be conferred. After graduation the candidate undergoes further education to develop professional competence in the industry. This will require a candidate to undergo training and gain experience in order to register either as a Professional Engineer ( $\mathrm{Pr}$ Eng), Professional Engineering Technologist (Pr Eng Tech), or a Professional Engineering Technologist (Pr Eng Techn), to mention a few examples. The next phase will be dedicated to observing code of conduct and maintaining competence through lifelong learning; and there is a 5-year professional registration renewal. The important information about postgraduate training is clearly set out in the 'Training and Mentoring Guide for Specified Categories' document published by ECSA. It is important to note that ECSA uses the term WIL to refer to the learning/training and development of engineering graduates towards complying with the prescribed registration requirements.

\section{Managing work-integrated learning}

The successful managing of WIL relies heavily on academic leadership. The university department in this case plays a very important role. While the task of managing WIL will be undertaken largely by university teachers, it is obviously much easier for university teachers, heads of departments, and heads of programmes to manage WIL when there are clear institutional guides, policies, and resources for WIL programmes. With regard to the administrative aspects of management, in the Good Practice Guide and self-evaluation instruments for managing the quality service learning, a very useful resource is the list of 15 criteria for programme accreditation (HEQC, 2004). These accreditation criteria indicate important elements that should form part of an effective curriculum to facilitate quality learning.

From Table IV it can be seen that any effective programme, according to the CHE, should be informed by many aspects, ranging from programme design, student recruitment and staffing, to the coordination of work-based learning. Universities that opt for the diploma programmes in the new curriculum are expected to consider the 15 criteria for programme accreditation in designing the WIL component of the advanced certificate.

The other accreditation is that of ECSA, which involves the accreditation of engineering programmes on a 4-year cycle. The aim of this accreditation visit to institutions aims is to approve the engineering programmes of a specific tertiary educational institution, inclusive of providing concomitant financial support to the institution. This process

\begin{tabular}{|l|l}
\hline \multicolumn{2}{|l}{$\begin{array}{l}\text { Table IV } \\
\text { Criteria for programme accreditation }\end{array}$} \\
\hline Criterion & Areas \\
\hline 1 & Programme design \\
\hline 2 & Student recruitment, admission, and selection \\
\hline 3 and 4 & Staffing \\
\hline 5 & Teaching and learning strategy \\
\hline 6 & Student assessment policies and procedures \\
\hline 7 & Infrastructure and library resources \\
\hline 8 & Programme administrative services \\
\hline 9 & Postgraduate policies, regulations, and procedures \\
\hline 10 & Programme coordination \\
\hline 11 & Academic development for student success \\
\hline 12 & Teaching and learning interactions \\
\hline 13 and 14 & Student assessment and practices \\
\hline 15 & Coordination of work-based learning \\
\hline
\end{tabular}




\section{A review of work-integrated learning in South African mining engineering universities}

is designed to ensure that graduates exiting from the institution meet the learning outcomes prescribed for this purpose by ECSA/CHE. In both of the two accreditations, quality maintenance is crucial.

For an ODL institution such as Unisa, any deficiency in study material can be addressed by the review cycle curriculum in a period of seven years that is stipulated in their curriculum policy. Unisa, like most universities, acknowledges that WIL plays a crucial role in the attaining of professional qualifications, but there are other factors that mitigate against this acknowledgement.

Over-emphasis on research is an impediment to managing an effective WIL programme. Teaching and learning are not given the same attention as research, and that creates an impression that tuition and learning issues can be attended to later. The merger between the former technikons and universities to form comprehensive universities has led to a lack of appreciation of technology programmes by senior managers in some of the universities. Such an environment affects the provision of WIL and student-centredness since experiential learning focuses on the development of a student.

\section{Current trends}

One approach that can assist in overcoming the deficiency of professional education and industry dissatisfaction has been suggested. Situated in the field of the sociology of education, the research draws primarily on the work of Bernstein (2000) and Maton (2014). This is basically a cutting-edge sociological approach to describe the structuring of design knowledge. Design knowledge is composed of theories, practices, principles, cases, guidelines, patterns, and cognitive strategies. It has been applied in many areas including business strategy, technological innovation, management theory, and educational curriculum and human development policy (Maton, Dong, and Carvalho, 2014).

Since there is a great deal of complexity involved in understanding the whole concept of design knowledge, a multi-dimensional framework for analysing the organizing principles of knowledge practices has been developed, termed legitimation code theory (LCT). LCT seems to be the most popular instrument currently used in social realist research. Social realist research explores the organizing principles of different forms of knowledge, their modes of change, and their implications for issues such as social inclusion, student achievement, and knowledge-building (Maton and Moore, 2010).

Engineering in general offers an ideal environment to interrogate the relationship between theoretical, technological, and context-specific practical knowledge which encompasses many disciplines in one. WIL forms one part of engineering education where the different knowledge forms of different disciplines have to be integrated. It is therefore necessary for university teachers to consider the fundamentals offered in the structuring of design knowledge. Current trends are important to observe as they provide an opportunity for university teachers to be aware of new possibilities and to improve their teaching skills based on new ideas that are emerging. There is no doubt that in South Africa we still need to do more on WIL, considering what other countries have done.

\section{Conclusion}

WIL will remain important for years to come, as the literature indicates, and for the reason that practice is part of education for professional qualifications. In an unequal society such as South Africa, WIL can be used to bring about equity and excellence in the workplace.

This paper has summarized all the important elements of WIL in order to provide industry and tertiary institutions with a broader view of how WIL is conducted. This will help to identify possible areas of improvement in mining engineering programmes, although this also applies to all engineering programmes.

The history of apartheid and the struggle of the working class and students have shown that training and development is crucial. The formation of the NQF in 1995 created opportunities for South Africans to address this need. Since then, positive outcomes have emerged universities are addressing challenges of student placement using different approaches, development of a new curriculum for WIL with the support of ECSA has started, and the UP Virtual Reality Centre and Wits DigiMine project are examples of progress in addressing education and training in South Africa.

Despite the positive developments mentioned above, WIL programmes face challenges that need attention. These challenges include student placement in the industry, further improvement of the WIL curriculum and programmes, improvement of pedagogical skills for university teachers in engineering, availability of suitable mentors, environments conducive for training and development in the industry, and effective partnerships to improve WIL.

\section{Recommendations}

In the light of the discussion presented in this paper, the recommendations below will help in improving the WIL offering.

> More research needs to be done to study the environment in the mining industry to determine whether the current culture affects the development and training of people, and if this is indeed so, ascertain to what extent and identify the main contributors. This is so because no amount of curriculum design can compensate for a hostile environment for learning. This research can help to advance the goals of the NQF. The CEOs can help to prepare for such an exercise as industry resistance to WIL may defeat the whole purpose.

> The training of university teachers, encompassing teaching as delivery, programme design and evaluation, and the scholarship of teaching and learning, is critical. The curricular modalities of WIL programmes presented by the $\mathrm{CHE}$ are diverse in approach as they integrate classroom and workplace environments. Engineering is an ideal environment in which to interrogate the relationship between theoretical, technological, and context-specific practical knowledge, since it encompasses many disciplines and requires the skills that have been mentioned above. In this case, the current LCT approach may be helpful to identify a curriculum design that enables students to realize their full potential for growth. For this to be 


\section{A review of work-integrated learning in South African mining engineering universities}

effective, university teachers need to research and apply the effectiveness of any programme they introduce.

\section{Abreviations/acronyms}

BEng: Bachelor of Engineering

BSc (Eng): Bachelor of Science in Engineering

CHE: Council on Higher Education

COSATU: Congress of South African Trade Unions

HEQC: Higher Education Quality Committee

ECSA: Engineering Council of South Africa

ITL: Improving teaching and learning

LCT: Legitimation code theory

NEPI: National Education Policy Initiative

MQA: Mining Qualifications Authority

NQF: National Qualifications Framework

PBL: Problem-based learning

PJBL: Project-based learning

PQM: Programme and qualifications mix

Pr Cert Eng: Professional Certificated Engineer

Pr Eng: Professional Engineer

Pr Tech Eng: Professional Engineering Technologist

RPL: Recognition of prior learning

SAQA: South African Qualifications Authority

SETA: Sector Education and Training Authority

WDTL: Word-directed theoretical training

WIL: Work-integrated learning

WPL: Workplace learning

\section{References}

BERnSTeIn, B. 2000. Pedagogy, Symbolic Control, and Identity: Theory, Research, Critique (revised. edn). Rowman and Littlefield, New York.

BIGGS, J. 1999. Teaching for Quality Learning at University: What the Student Does. Open University Press and Society for Research into Higher Education, Buckingham, UK.

BlicblaU, A.S., Nelson, T.L., and Din, K. 2016. The Role of Work Placement in Engineering Students' Academic Performance. Swinburne University of Technology, Melbourne, Australia.

BRAVENBoER, D. and LeSTER, S. 2016. Towards an integrated approach to the recognition of professional competence and academic learning. Education + Training, vol. 58, no. 4. pp. 409-421.

CHE, see Council on Higher Education.

Council on Higher Education. 2005. Annual Report. HE Monitor, no. 12. Pretoria. http://www.che.ac.za/media_and_publications/annualreports/annual-report-council-higher-education-20042005 [accessed 20 November 2017].

COUNCiL on Higher Education. 2011. Work-integrated learning: good practice guide. HE Monitor, no. 12. Pretoria.

http://www.che.ac.za/sites/default/files/publications/Higher_Education_M onitor_12.pdf [accessed 19 October 2017].

Council on Higher Education. 2017. Learning to teach in higher education in South Africa. HE Monitor no. 14.

http://www.che.ac.za/media_and_publications/higher-educationmonitor/higher-education-monitor-14-learning-teach-higher [accessed 12 November 2017]

DEwEY, J. 1938. Experience and Education. MacMillan, New York.

Drysdale, M.T.B., McBeath, M.L., Johansson, K., Dressler, S., and Zaitseva, E. 2016. Psychological attributes and work-integrated learning: An international study. Higher Education, Skills and Work-Based Learning, vol. 6, no. 1. pp. 20-34.

ENGINEERING Council of South Africa. 2016. Training and mentoring guide for specified categories. Document R-04-SC

Gamble, N., Patrick, C., and PeAch, D. 2010. Internationalising work integrated learning: creating global citizens to meet the economic crisis and the skills shortage. Higher Education Research \& Development, vol. 29, no. 5. pp. 535-546. doi: 10.1080/07294360.2010.502287

Higher Education Quality CommitTeE. 2004. Criteria for programme accreditation. Council on Higher Education, Pretoria. http://www.che.ac.za/media_and_publications/publications/higher_educat ion_monitors [accessed June 2017].

JACKSON, D. and WiLToN, N. 2016. Developing career management competencies among undergraduates and the role of work-integrated learning. Teaching in Higher Education, vol. 21, no. 3. pp. 266-286. doi: 10.1080/13562517.2015.1136281

KolB, D. 1984. Experiential Learning. Prentice Hall, Englewood Cliffs, NJ.

Maton, K. 2014. Knowledge and Knowers: Towards a Realist Sociology of Education. Routledge, London.

MAton, K. and Moore, R. 2010. Introduction: coalitions of the mind. Social Realism, Knowledge and the Sociology of Education: Coalitions of the Mind. Maton, K. and Moore, R. (eds). Continuum, New York. pp. 1-13.

Maton, K., Dong, A., and Carvalho, L. 2014. The structuring of design knowledge. Routledge Companion to Design Research. Rodgers, P. and Yee, J. (eds). Routledge, London/Sydney, Australia.

MoReland, N. 2005. Work-related Learning in Higher Education. The Higher Education Academy, Heslington, York:

ORRELL, J. 2004. Work-integrated learning programmes: Management and educational quality. Proceedings of the Australian Universities Quality Forum 2004. https://tls.vu.edu.au/vucollege/LiWc/ resources/orrell.pdf [accessed 15 April 2016].

Patrick, C-J., Peach, D., Pocknee, C., Webb, F., Fletcher, M., and Pretto, G. 2008. The WIL (Work Integrated Learning) report: A national scoping study. Australian Learning and Teaching Council (ALTC) Final Report. Queensland University of Technology, Brisbane. http://www.altc.edu.au and http://www.acen.edu.au

Pennaforte, A. 2015. Organizational supports and individuals commitments through work integrated learning. Higher Education, Skills and WorkBased Learning, vol. 6, no. 1. pp. 89-99.

SAQA. 2010. NQF history. http://www.saqa.org.za [accessed 26 August 2018].

SAQA. 2002. NQF consultative document. http://www.saqa.org.za/docs/reports/2003/nqf_consultativedoc.pdf [accessed 26 August 2018].

ScHön, D.A. 1983. The Reflective Practitioner: How Professionals Think in Action. Jossey-Bass, New York, NY.

SмIтH, C. 2012. Evaluating the quality of work-integrated learning curricula: A comprehensive framework. Higher Education Research \& Development, vol. 31, no. 2. pp. 247-262. doi: 10.1080/07294360.2011.558072

Smith, M., Brooks, S., Lichtenberg, A., Mcllveen, P., Torjul, P., and Tyler, J. 2009. Career development learning: Maximizing the contribution of workintegrated learning to the student experience. Australian Learning and Teaching Council. Final Project Report June 2009. Careers Central, Academic Services Division, University of Wollongong.

UNIVERSITY OF JOHANNESBURG. 2007. Work integrated learning and service policy. Document no. 5P/5.11.

https://www.uj.ac.za/about/Documents/policies/Policy\%20on\%20\%20wo rk\%20Integrated\%20Learning\%20and\%20Service\%20Learning\%20 (appro ved\%20by\%20Senate $\% 205 \% 20$ June $\% 202014$ ).pdf [accessed 10 October 2017].

UP. 2018. Virtual reality centre. https://www.up.ac.za/virtual-reality-centre [accessed 26 August 2018].

University of South AFricA. 2015. Policy: experiential learning. http://staffcmsys.unisa.ac.za/cmsys/staff/contents/departments/tuition_p olicies/docs/Policy\%20-\%20\%20Experiental\%20Learning\%20\%20rev\%20appr\%20Council\%20-\%2005.07.2015.pdf [accessed 10 November 2017].

Wits Mining InSTITUTE. 2018. DigiMine laboratory. https://www.wits.ac.za/wmi/digimine/ [accessed 26 August 2018].

YoRKe, M. 2006a. Employability in higher education: what it is - what it is not The Higher Education Academy, Heslington, York.

YoRKe, M. (ed.). 2006b. Learning \& employability series 1 and 2. The Higher Education Academy, Heslington, York.

YoRKE, M. and KNIGHT, P.T. 2006. Embedding employability into the curriculum. The Higher Education Academy, Heslington, York. 